\title{
Tariff Relief and Promoting Free Trade Agreement Between China and Norway
}

\author{
Nianlin Zhou ${ }^{\mathrm{a} 1}$ Jin $_{\mathrm{Guo}}^{\mathrm{b}}$ and Manyuan Jiang ${ }^{\mathrm{a}}$ \\ ${ }^{a}$ South China Business College, Guangdong University of Foreign Studies, \\ Guangzhou, China \\ ${ }^{\mathrm{b}}$ College of Management, Guangdong AIB Polytechnic, Guangzhou, China
}

\begin{abstract}
Tariff relief is a prerequisite for reaching a free trade agreement. This study employs quantitative indicators to identify the specific types of goods with trade complementarity between China and Norway based on the published data by the United Nations, the World Trade Organization and the National Bureaus of statistics both in China and Norway. The empirical results confirm that some types of commodities are provided with trade complementarity between both sides. Nevertheless, these complementary goods are imposed tariffs on each other. The consequences are linked with aggravating resources shortage in China on the one hand, and limiting consumption in Norway on the other. Therefore, pushing up tariff relief is favor of mutual benefit cooperation and making progress in the negotiation of free trade agreement between China and Norway.
\end{abstract}

Key words. Tariff Relief; free trade agreement; trade complementarity

\section{Introduction}

Free trade agreement is the key to promote free trade zone. The establishment of free trade zone is usually based on the signing of free trade agreement (FTA). Recent years, FTA has become an important paradigm to enhance economic and trade cooperation between China and countries along "the belt and road".

As the part of "the belt and road", the Nordic countries have been pursuing free trade policy for a long time and have expressed strong complementarity with Chinese industries. Iceland has established a free trade zone with China in 2013. The negotiations of free trade agreement between China and Norway have conducted the 16th round so far.

The fundamental content of free trade agreement is tariff relief [1].The important premise of reaching FTAs involves the types, range and size of goods for tariff relief. Moreover, the expansion of bilateral trade volume caused by tariff relief means extending free trade further and increasing the possibility to reach a FTA for both sides.

Many studies have provided a lot of valuable research on the role and effect of free trade zone. The free trade zone is defined as the elimination of tariff and non-tariff

\footnotetext{
${ }^{1}$ Corresponding Author: Nianlin Zhou, South China Business College, Guangdong University of Foreign Studies, Guangzhou, China; Email: gweduyj@163.com. This research was funded by the Education Bureau of Guangdong Province of China (Grant No. 2018GXJK272) and the research center of polar issues of South China Business College, Guangdong University of Foreign Studies (Grant No. NGJD 201901) and (Grant No. 20 JD004A).
} 
barriers between countries or regions through the signing of free trade agreements [2]. Countries with high production costs will benefit from the expansion of trade size and trade creation effect [3]. Moreover, free trade zone (FTZ) is a new way of economic and political interdependence that promotes the combination of national or regional development strategy and international process. The most direct goal of the FTZ is to expand the mutual trade among member countries and to form a larger market scale so that enhance international competitiveness [4]. In addition, some scholars have paid attention to the effects of establishing FTZ between China and other countries. China and ASEAN Free Trade Area, for example, the trade flow between member countries with similar per capita income and demand structure might increase [3]. The income distribution of the Asia Pacific free trade area is different among member countries. The developed countries, represented by the United States, get more additional income than the developing countries [5].

Others find that trade complementarity is an important way to promote the FTZ [6]. The difference of resource endowment has become the decisive factor of trade complementarity between China and the countries or regions along "the belt and road" [7]. The complementarity of agricultural product transaction between China, Norway and Finland is weak, but is strong with Sweden, Denmark and Iceland [8]. If establish a FTZ, it will enhance the cooperation in the field of high technology due to the complementarity of inter industry trade between China and Norway [9]. Generally, the potential and huge benefits will be stimulated by signing the free trade agreement (FTA) as long as there is industrial structural complementarity between trade partners [10]. However, the average import efficiency from the countries along "the bet and road" is lag behind the average level of export from China [11].

In terms of tariff relief, the basic content of reaching a FTA, almost all of the FTA in the world have covered the tariff relief for manufactured and agricultural products [12]. Since tariff reduction will make contribution to significantly increase the volumes of export and import products [1] [13], and to add the diversity of trade goods as well [14].

Current studies discuss the macro-economic effect in building the FTZ, but lack deep analysis about the influence of tariff relief on import volume and consumption demand with complementary goods in bilateral trade and on the FTA.

Particularly, China has become the eighth largest export market and the fifth largest import source of Sweden, the seventh largest export market and the fourth largest import source of Denmark, the third largest source of imports and ninth largest export market of Norway, and the fifth largest import and export market of Finland in 2019 according to the data of Eurostat. Moreover, compared with the major Nordic countries, Norway has become an important trading partner with China, second only to Sweden (see Figure 1). 


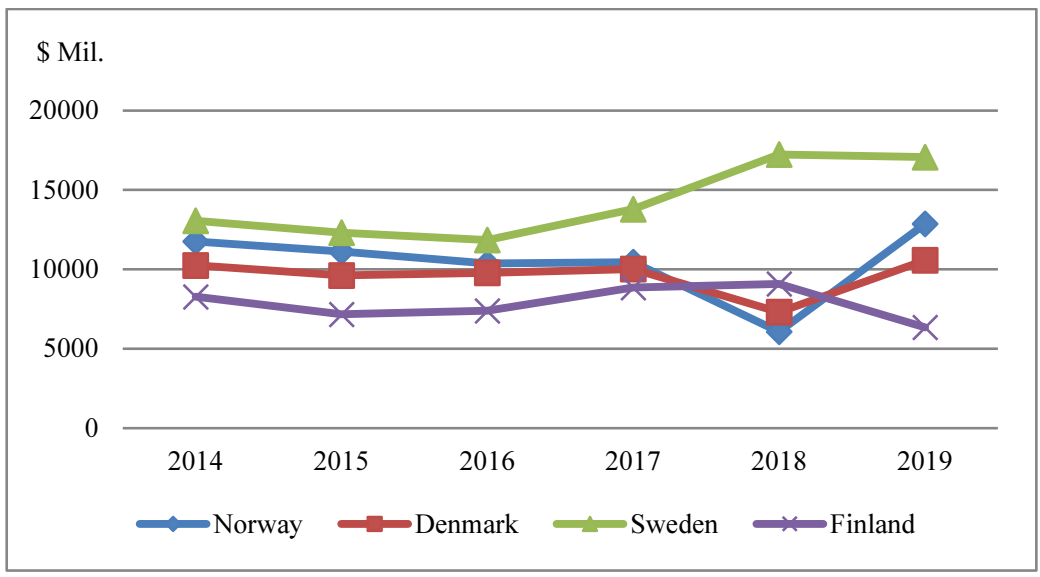

Figure 1. The total volume of import and export of Norway, Denmark, Sweden and Finland to China (2014-2019)

Source: The results of Figure 1 is obtained as per the international trade data of the United Nations, Eurostat and general administration of customs of China.

How to further promoting economic cooperation between Norway and other Nordic countries should be the focus of research. The possible contribution of this article is to identify the commodities with trade complementary through applying the trade complementarity index in accordance with data of international economic organizations and national statistics, and to analyze the impact of tariff on the import volume of complementary products for both sides. The suggestion is to decrease or to abolish tariffs on goods with strong complementarity first, so that take it as a breakthrough to promote new progress in FTA negotiation between China and Norway.

\section{Identifying the commodities of trade complementarity between China and Norway}

It is the basic condition for promoting the mutual benefit and positive sum game by means of identifying the types of complementary goods between China and Norway. This study classifies all commodities according to the classification standard of the United Nations International Trade Classification (SITC Rev. 3) (see Table 1), so as to clarify the specific commodity types related to the trade complementarity between both sides, and avoid too general description about complementary goods to carry out policy measures. 
Table 1. The standard of international trade classification of United Nations (SITC Rev. 3)

\begin{tabular}{|c|c|c|}
\hline \multicolumn{2}{|c|}{ Classification of SITC Rev.3 } & Description of classified products \\
\hline SITC 0 & Food and & \\
\hline SITC 1 & Beverage & \\
\hline SITC 2 & $\begin{array}{l}\text { Crude ray } \\
\text { wood cor } \\
\text { copper ni }\end{array}$ & $\begin{array}{l}\text { ials other than fuel, including: raw fur, rubber, oilseeds, } \\
\text { lemp textile fiber, sand and gravel abrasive, pyrite, iron } \\
\text { ) }\end{array}$ \\
\hline SITC 3 & Fossil fue & \\
\hline SITC 4 & Fats and & \\
\hline SITC 5 & Chemical & \\
\hline SITC 6 & $\begin{array}{l}\text { Manufact } \\
\text { steel prod }\end{array}$ & $\begin{array}{l}\text { terials(leather products, textiles, non-ferrous metals, } \\
\text { mic products, paper and paperboard products) }\end{array}$ \\
\hline SITC 7 & Machiner & \\
\hline SITC 8 & $\begin{array}{l}\text { Miscellan } \\
\text { house san }\end{array}$ & $\begin{array}{l}\text { ag and furniture, lighting and photographic equipment, } \\
\text { tc.) }\end{array}$ \\
\hline SITC 9 & $\begin{array}{l}\text { Unclassif } \\
\text { gold ore) }\end{array}$ & (coins-non legal tender, non-monetary gold-excluding \\
\hline
\end{tabular}

\footnotetext{
Source: The international trade database of United Nations.
Note: As SITC $0+1$ and SITC $2+4$ are consolidated in the statistical classification of the above database, and thus SITC $0+1$ and SITC $2+4$ are combined in the following calculation in this paper. In addition, SITC 9 is not included in the study because it is not a widely traded commodity.
}

\subsection{The 'revealed' comparative advantage of China and Norway}

The index of 'revealed' comparative advantage (RCA), an index for evaluating export comparative advantage and its international competitiveness of a country, is selected to measure the export comparative advantage for both countries. The formula of revealed comparative advantage index is:

$\operatorname{RCA}^{\mathrm{A}}{ }_{\mathrm{xi}}=\left(\mathrm{X}_{\mathrm{i}}^{\mathrm{A}} / \mathrm{X}_{\mathrm{i}}\right) /\left(\mathrm{X}^{\mathrm{A}}{ }_{\mathrm{W}} / \mathrm{X}_{\mathrm{W}}\right)$

Where $\mathrm{RCA}^{\mathrm{A}}$ xi means the export comparative advantage index of country $\mathrm{i}$ in commodity $\mathrm{A}$, and $\mathrm{X}^{\mathrm{A}}{ }_{\mathrm{i}}$ and $\mathrm{X}^{\mathrm{A}} \mathrm{W}$ separately involve the export volume of country $\mathrm{i}$ and the world in product $\mathrm{A}, \mathrm{X}_{\mathrm{i}}$ and $\mathrm{X}_{\mathrm{W}}$ express the total export of country $\mathrm{i}$ and the world, respectively. When the revealed comparative advantage index (RCA) is more than or equal to 2.5 , it illustrates that the export competitiveness of this commodity is very strong. If the RCA $>1$, the commodity has a comparative advantage in world exports, otherwise, it is weak.

The calculation results of RCA formula is shown by Table 2 in which presents that Chinese products with export comparative advantage for Norway include three categories: raw material products (SITC 6), machinery and transportation equipment (SITC 7) and miscellaneous products (SITC 8). Because the critical value of RCA is greater than or equal to 1 .

As per the trend of export comparative advantage from 2008 to 2017, the comparative advantage of SITC 8 increased rapidly since the index value of RCA of SITC 8 was more than 2. The RCA of SITC 7 fluctuated slightly but its average value still remained at 1.44. The comparative advantage of SITC 6 was relatively stable due to the average value of RCA, 1.35. The RCA value of other commodities was less than 1 , which meant no export comparative advantage. 
Table 2. The revealed comparative advantage of export goods in China (2008 - 2017)

\begin{tabular}{llllllll}
\hline Year & SITC 0+1 & SITC 2+4 & SITC 3 & SITC 5 & SITC 6 & SITC 7 & SITC 8 \\
\hline 2008 & 0.224722 & 0.200551 & 0.015612 & 0.461114 & 0.798843 & 1.65053 & 1.653093 \\
2009 & 0.419008 & 0.191114 & 0.123615 & 0.461997 & 1.256529 & 1.477847 & 1.451291 \\
2010 & 0.43905 & 0.178183 & 0.113664 & 0.516612 & 1.258859 & 1.484331 & 1.61573 \\
2011 & 0.444462 & 0.181205 & 0.099113 & 0.578156 & 1.333935 & 1.507345 & 1.857 \\
2012 & 0.424401 & 0.16992 & 0.085027 & 0.538652 & 1.369643 & 1.492561 & 2.258569 \\
2013 & 0.402386 & 0.162679 & 0.089499 & 0.5237 & 1.376928 & 1.473915 & 2.313704 \\
2014 & 0.390203 & 0.174482 & 0.0928 & 0.547597 & 1.416243 & 1.390803 & 2.27559 \\
2015 & 0.38557 & 0.169204 & 0.109167 & 0.522596 & 1.403972 & 1.315355 & 2.059561 \\
2016 & 0.41776 & 0.169795 & 0.138632 & 0.519241 & 1.381799 & 1.272734 & 2.015575 \\
2017 & 0.414315 & 0.164022 & 0.150758 & 0.574912 & 1.359937 & 1.338612 & 2.022959 \\
\hline
\end{tabular}

Source: The results of Table 2 is obtained by using the formula of RCA to calculate according to data of international trade data of the United Nations, the world trade organization and the national bureau of statistics of China from 2008 to 2017.

Over the same period, there were two types of resource intensive products expressed remarkable export comparative advantage in Norway (see Table 3). SITC 3, for example, was very strong with more than 4 of the RCA value and reached 5.79 in 2016. The export comparative advantage of SITC $0+1$ was gradually increased and the average value of RCA was 1.2. However, the RCAs of the rest did not indicate export competitive advantage $(\mathrm{RCA}<1)$.

Table 3. The revealed comparative advantage of export goods in Norway (2008-2017)

\begin{tabular}{lcllllll}
\hline Year & SITC 0+1 & SITC 2+4 & SITC 3 & SITC 5 & SITC 6 & SITC 7 & SITC 8 \\
\hline 2008 & 0.755146 & 0.283107 & 3.960044 & 0.245600 & 0.653422 & 0.279400 & 0.159072 \\
2009 & 0.906693 & 0.302748 & 4.724704 & 0.286198 & 0.635979 & 0.338554 & 0.156100 \\
2010 & 1.031400 & 0.381097 & 4.655100 & 0.31011 & 0.70976 & 0.282005 & 0.147842 \\
2011 & 0.993666 & 0.324286 & 3.952567 & 0.275335 & 0.623594 & 0.248177 & 0.176155 \\
2012 & 0.904495 & 0.369216 & 3.900466 & 0.218909 & 0.574747 & 0.250705 & 0.213723 \\
2013 & 1.094083 & 0.382814 & 3.932067 & 0.229946 & 0.584351 & 0.273153 & 0.226455 \\
2014 & 1.190636 & 0.437176 & 4.065533 & 0.256974 & 0.609723 & 0.290087 & 0.235483 \\
2015 & 1.310207 & 0.500147 & 5.174210 & 0.302896 & 0.698820 & 0.328463 & 0.261614 \\
2016 & 1.754480 & 0.526113 & 5.794143 & 0.350653 & 0.735263 & 0.324753 & 0.268368 \\
2017 & 1.637383 & 0.474539 & 5.513847 & 0.332156 & 0.734788 & 0.270672 & 0.236565 \\
& & & & & & & \\
\hline
\end{tabular}

Source: The results of Table 3 is obtained by using the formula of RCA to calculate according to data of international trade data of the United Nations, the world trade organization and the national bureau of statistics of Norway from 2008 to 2017.

\subsection{The 'Revealed' import comparative disadvantage of China and Norway}

The index of 'revealed' comparative disadvantage (RCD) is widely applied to measure the comparative disadvantage in producing or importing specific commodity of a country. The revealed comparative disadvantage index (RCD) can be expressed as:

$$
\operatorname{RCD}^{\mathrm{A}}{ }_{\mathrm{mj}}=\left(\mathrm{M}_{\mathrm{j}}^{\mathrm{A}} / \mathrm{M}_{\mathrm{j}}\right) /\left(\mathrm{M}^{\mathrm{A}}{ }_{\mathrm{W}} / \mathrm{M}_{\mathrm{W}}\right)
$$

Where $\mathrm{RCD}^{\mathrm{A}}{ }_{\mathrm{mj}}$ represents the import comparative disadvantage index of country $\mathrm{j}$ for goods $\mathrm{A}, \mathrm{M}_{\mathrm{j}}^{\mathrm{A}}$ is the import volume of $\mathrm{A}$ commodity of country $\mathrm{j}, \mathrm{M}_{\mathrm{j}}$ means the total import volume of country $\mathrm{j}, \mathrm{M}^{\mathrm{A}} \mathrm{W}$ refers to the import volume of world of product $\mathrm{A}$, and $\mathrm{M}_{\mathrm{W}}$ is the total import volume of the world. If $\mathrm{RCD}_{\mathrm{mj}}^{\mathrm{A}}>1$, it indicates a comparative disadvantage both in the production and import of product $\mathrm{A}$ in country $\mathrm{j}$.

Table 4 and table 5 are the results of using the formula of RCD to measure the import comparative disadvantage of China and Norway, respectively. There are three types of goods with import comparative disadvantage in China, including SITC 3, SITC $2+4$ and SITC 7 (see Table 4). Among them, SITC $2+4$ have the biggest import comparative disadvantage owing to its RCD is more than 4, even though declines after 2016, still higher than 3.16. During the nine-year period from 2009 to 2017, Chinese import demand for SITC 3 and SITC 7 was strong $(\operatorname{RCD}>1)$ which implied the 
shortage of those commodities in China.

Table 4. The revealed comparative disadvantage of import goods in China (2008-2017)

\begin{tabular}{|c|c|c|c|c|c|c|c|}
\hline Year & SITC $0+1$ & SITC $2+4$ & SITC 3 & SITC 5 & SITC 6 & SITC 7 & SITC 8 \\
\hline 2008 & 0.590681 & 0.29527 & 0.209935 & 0.528153 & 0.93832 & 1.805158 & 1.364172 \\
\hline 2009 & 0.244802 & 5.010623 & 0.887799 & 0.972409 & 0.891796 & 1.373388 & 0.504159 \\
\hline 2010 & 0.277571 & 4.490528 & 0.900858 & 0.96212 & 0.76731 & 1.338907 & 0.562489 \\
\hline 2011 & 0.294669 & 4.328462 & 0.918676 & 0.941401 & 0.699318 & 1.278152 & 0.576681 \\
\hline 2012 & 0.35039 & 4.343187 & 0.969233 & 0.920865 & 0.698295 & 1.263373 & 0.695401 \\
\hline 2013 & 0.36741 & 4.455592 & 0.947198 & 0.900874 & 0.663855 & 1.270136 & 0.673148 \\
\hline 2014 & 0.393886 & 4.426294 & 1.022617 & 0.894669 & 0.747819 & 1.257872 & 0.663857 \\
\hline 2015 & 0.480798 & 4.466419 & 1.074015 & 0.890647 & 0.676215 & 1.294549 & 0.690631 \\
\hline 2016 & 0.487454 & 4.621081 & 1.177042 & 0.883231 & 0.656253 & 1.274892 & 0.673933 \\
\hline 2017 & 0.472035 & 3.161206 & 1.24079 & 0.917028 & 0.636521 & 1.093867 & 0.645583 \\
\hline
\end{tabular}

Source: The results of Table 4 is obtained by using the formula of RCD to calculate as per data of international trade data of the United Nations, the world trade organization and the national bureau of statistics of China from 2008 to 2017.

Table 5 reports that five categories of products of Norway have import comparative disadvantage. Based on the order from high to low of import comparative disadvantage in 2017, SITC 6 has the highest import comparative disadvantage, followed by SITC $2+4$, SITC 8, SITC 7 and SITC 0+1.The index values of RCD for those group goods are all more than 1, and thus confirm there are a strong import demand for these products, especially for SITC 6 in Norway.

Table 5. The revealed comparative disadvantage of import goods in Norway (2008-2017)

\begin{tabular}{|c|c|c|c|c|c|c|c|}
\hline Year & SITC $0+1$ & SITC 2+4 & SITC 3 & SITC 5 & SITC 6 & SITC 7 & SITC 8 \\
\hline 2008 & 1.069645 & 2.529438 & 0.281721 & 0.852741 & 1.252265 & 1.36969 & 1.009783 \\
\hline 2009 & 1.082072 & 2.20536 & 0.358126 & 0.865792 & 1.25719 & 1.350053 & 0.932769 \\
\hline 2010 & 1.116182 & 2.155827 & 0.436114 & 0.865119 & 1.198074 & 1.307791 & 1.026885 \\
\hline 2011 & 1.125976 & 2.112751 & 0.370559 & 0.834193 & 1.198267 & 1.355258 & 1.139269 \\
\hline 2012 & 1.221223 & 2.026445 & 0.342149 & 0.843441 & 1.320951 & 1.342006 & 1.377953 \\
\hline 2013 & 1.226927 & 1.897206 & 0.41185 & 0.826468 & 1.259975 & 1.356997 & 1.424652 \\
\hline 2014 & 1.223017 & 2.026531 & 0.334176 & 0.834644 & 1.29336 & 1.332163 & 1.431687 \\
\hline 2015 & 1.175403 & 2.211603 & 0.393308 & 0.801059 & 1.200599 & 1.280051 & 1.393118 \\
\hline 2016 & 1.20437 & 2.182406 & 0.377018 & 0.839804 & 1.198277 & 1.228296 & 1.415325 \\
\hline 2017 & 1.099662 & 1.391913 & 0.410331 & 0.843258 & 1.465317 & 1.065188 & 1.319775 \\
\hline
\end{tabular}

Source: The results of Table 5 is obtained by using the formula of RCD to calculate based on data of intemational trade data of the United Nations, the world trade organization and the national bureau of statistics of Norway from 2008 to 2017.

\subsection{Trade complementarity between China and Norway}

Trade complementarity index (TCI) is a quantitative index to measure the degree of trade complementarity among trading partner countries. The calculation formula is as follows:

$\mathrm{TCI}^{\mathrm{A}_{\mathrm{ij}}}=\mathrm{RCA}^{\mathrm{A}}{ }_{\mathrm{xi}} \times \mathrm{RCD}^{\mathrm{A}}{ }_{\mathrm{Mj}}=\left(\mathrm{X}_{\mathrm{i}}^{\mathrm{A}_{\mathrm{i}}} / \mathrm{X}_{\mathrm{i}}\right) /\left(\mathrm{X}_{\mathrm{W}}^{\mathrm{A}} / \mathrm{X}_{\mathrm{W}}\right) \times\left(\mathrm{M}_{\mathrm{j}}^{\mathrm{A}} / \mathrm{M}_{\mathrm{j}}\right) /\left(\mathrm{M}^{\mathrm{A}}{ }_{\mathrm{W}} / \mathrm{M}_{\mathrm{W}}\right)$

Where $\mathrm{TCI}^{\mathrm{A}}{ }_{\mathrm{ij}}$ means trade complementarity index of country $\mathrm{i}$ and country $\mathrm{j}$ in commodity $\mathrm{A}, \mathrm{RCA}^{\mathrm{A}}{ }_{\mathrm{xi}}$ indicates trade comparative advantage of country $\mathrm{i}$ in exporting product $A, R^{A}{ }^{A}$ jefers to comparative disadvantage of country $\mathrm{j}$ in importing merchandise A. When TCI $>1$, it expresses the existence of the trade complementarity in product $\mathrm{A}$ between country $\mathrm{i}$ and country $\mathrm{j}$, instead, it is low.

Table 6 presents that SITC 6, SITC 7 and SITC 8 of China have strong trade complementarity to Norway (TCI $>1$ ). Especially, the group of SITC 8 shows a stronger trade complementarity to Norway, while the trade complementarity SITC 6 is on the rise. 
Table 6. Trade complementarity goods of export by China and import from Norway (2008-2017)

\begin{tabular}{|c|c|c|c|c|c|c|c|c|}
\hline Year & SITC 0 & SITC 1 & SITC $2+4$ & SITC 3 & SITC 5 & SITC 6 & SITC 7 & SITC 8 \\
\hline 2008 & 0.016588 & 0.011737 & 0.083593 & 0.831352 & 0.129714 & 0.613119 & 0.504361 & 0.217002 \\
\hline 2009 & 0.024524 & 0.013012 & 1.516956 & 4.194587 & 0.278302 & 0.567164 & 0.464966 & 0.078699 \\
\hline 2010 & 0.034392 & 0.010985 & 1.711327 & 4.193584 & 0.298363 & 0.544606 & 0.377578 & 0.083159 \\
\hline 2011 & 0.030971 & 0.012704 & 1.403660 & 3.631128 & 0.259201 & 0.436091 & 0.317208 & 0.101585 \\
\hline 2012 & 0.038938 & 0.017231 & 1.603574 & 3.78046 & 0.201586 & 0.401343 & 0.316734 & 0.148623 \\
\hline 2013 & 0.043629 & 0.015579 & 1.705663 & 3.724446 & 0.207152 & 0.387924 & 0.346941 & 0.152438 \\
\hline 2014 & 0.053370 & 0.020177 & 1.935070 & 4.157483 & 0.229907 & 0.455962 & 0.364892 & 0.156327 \\
\hline 2015 & 0.073315 & 0.000004 & 2.233866 & 5.557179 & 0.269773 & 0.472553 & 0.425211 & 0.180679 \\
\hline 2016 & 0.096144 & 0.000006 & 2.431211 & 6.819950 & 0.309708 & 0.482519 & 0.414025 & 0.180862 \\
\hline 2017 & 0.094740 & 0.000004 & 1.500116 & 6.841526 & 0.304596 & 0.467708 & 0.296079 & 0.152722 \\
\hline
\end{tabular}

Source: The results of Table 7 is obtained by employing the formula of TCI to calculate based on data of international trade data of the United Nations, the world trade organization, the bureau of statistics of Norway, the national bureau of statistics of China and the national bureau of statistics of Norway from 2013 to 2018.

The Norwegian goods that can meet Chinese consumption demand involve SITC 3 and SITC $2+4$ (see Table 7). The TCI value of SITC 3 had been gradually rising from 4.9 of 2009 to 6.8 of 2017. In addition, Chinese import demand about SITC 0 is increasing. The prospects of complementary supply and demand of food products will be very broad as Norway is the largest aquaculture country for aquatic products, and China is one of the largest consumer countries of aquatic products in the world.

Table 7. Trade complementarity goods of export by Norway and import from China (2008-2017)

\begin{tabular}{|c|c|c|c|c|c|c|c|c|}
\hline Year & SITC 0 & SITC 1 & SITC 2+4 & SITC 3 & SITC 5 & SITC 6 & SITC 7 & SITC 8 \\
\hline 2008 & 0.038637 & 0.007875 & 0.507281 & 0.004398 & 0.393211 & 1.000363 & 2.260714 & 1.669265 \\
\hline 2009 & 0.045123 & 0.013362 & 0.421475 & 0.04427 & 0.399993 & 1.579696 & 1.995172 & 1.353719 \\
\hline 2010 & 0.049361 & 0.008929 & 0.384132 & 0.04957 & 0.446931 & 1.508206 & 1.941195 & 1.659169 \\
\hline 2011 & 0.050176 & 0.014801 & 0.382841 & 0.036727 & 0.482294 & 1.59841 & 2.042841 & 2.115623 \\
\hline 2 & 0.057412 & 0.017234 & 0.344334 & 0.029092 & 0.454321 & 1.809231 & 2.003026 & 3.112202 \\
\hline 2013 & 0.048574 & 0.016046 & 0.308636 & 0.03686 & 0.432821 & 1.734895 & 2.000098 & 3.296223 \\
\hline 14 & 0.048791 & 0.018562 & 0.353593 & 0.031012 & 0.457049 & 1.831712 & 1.852776 & 3.257933 \\
\hline 5 & 0.046932 & 0.019351 & 0.374212 & 0.042936 & 0.41863 & 1.685607 & 1.683721 & 2.869212 \\
\hline 2016 & 0.050808 & 0.022356 & 0.370562 & 0.052267 & 0.436061 & 1.655778 & 1.563294 & 2694 \\
\hline 2017 & 0.40074 & 0.163485 & 0.228304 & 0.061861 & 0.484799 & 1.992739 & 1.425873 & 2.669851 \\
\hline
\end{tabular}

Source: The results of Table 6 is obtained by employing the formula of TCI to calculate based on data of international trade data of the United Nations, the world trade organization, the bureau of statistics of Norway, the general administration of customs of China and the national bureau of statistics of China from 2013 to 2018

The complementary product structure illustrates that, on the one hand, Norwegian commodity with strongest export competition is SITC 3. The export comparative advantage of SITC $0+1$ needs to be supported by importing such goods. Furthermore, there are five categories with import comparative disadvantage, excepting SITC 3 and SITC 5. Thus, the export comparative advantage relies on a single category, SITC 3, while scarce goods highly depend on foreign import in Norway. On the other hand, Chinese export comparative advantages are concentrated on SITC 6, SITC 7 and SITC 8 , and the import comparative disadvantages focus on SITC $2+4$ and SITC 3 which indicate a large resource gap in China.

\section{Characteristics and tariffs of trade complementary commodities in China and Norway}

\subsection{Characteristics of trade complementary goods in China and Norway}

The product gradation of trade complementary provides that resource intensive products of Norway are major complementarity categories with China, such as fossil 
fuels. Meanwhile, some goods of China, including capital intensive products of SITC 6 and SITC 7and labor-intensive goods of SITC 8, are mainly complementarity products with Norway. The transaction between both sides is linked with inter-industry trade rather than intra-industry complementary trade.

In the light of the types of potential trade complementarity, SITC 2 of Norway and SITC 6 of China have prominent complementarity between the upper and lower industrial chains, which shows the characteristics of industrial division of labor with strong complementarity, and belongs to the type of potential complementarity enhancement. The bilateral trade volume of SITC 2 and SITC 6 should be greatly increased in the long run.

SITC 7 of China touches upon the type of potential expansion because problems of infrastructure construction in Norway where 615000 buildings are in the high decay hazard category, including Oslo and Hordaland. Moreover, the backlog in road, railway and offshore infrastructure maintenance make the operation of infrastructure extremely severe[15]. The situation of Norwegian infrastructure has not been significantly improved. It is possible for China to increase export of SITC 7 to Norway when familiar with the technical quality standards of Norwegian infrastructure and improve the quality accordingly.

The transaction of SITC 3 between Norway and China has great potentiality. The TCI of SITC 3 with China was as high as 6.8 in 2017. It means that China has strong import potential and huge market demand for this commodity.

The goods of SITC 0 refer to the type of potential excavation. Norway is the second largest exporter of live livestock and fish among the four Nordic countries (Denmark, Finland and Swede), of which salmon and sea cucumber are the scarce species for China. Yet, the average export of SITC $0+1$ of Norway was total US $\$ 10.9$ billion, but Chinese import from Norway was less than US $\$ 4.3$ billion in average from 2012 to 2017 (see Figure 2). Comparing with imported $\$ 15.7$ billion from the world in the same period, the import of SITC $0+1$ from Norway was around one fourth.

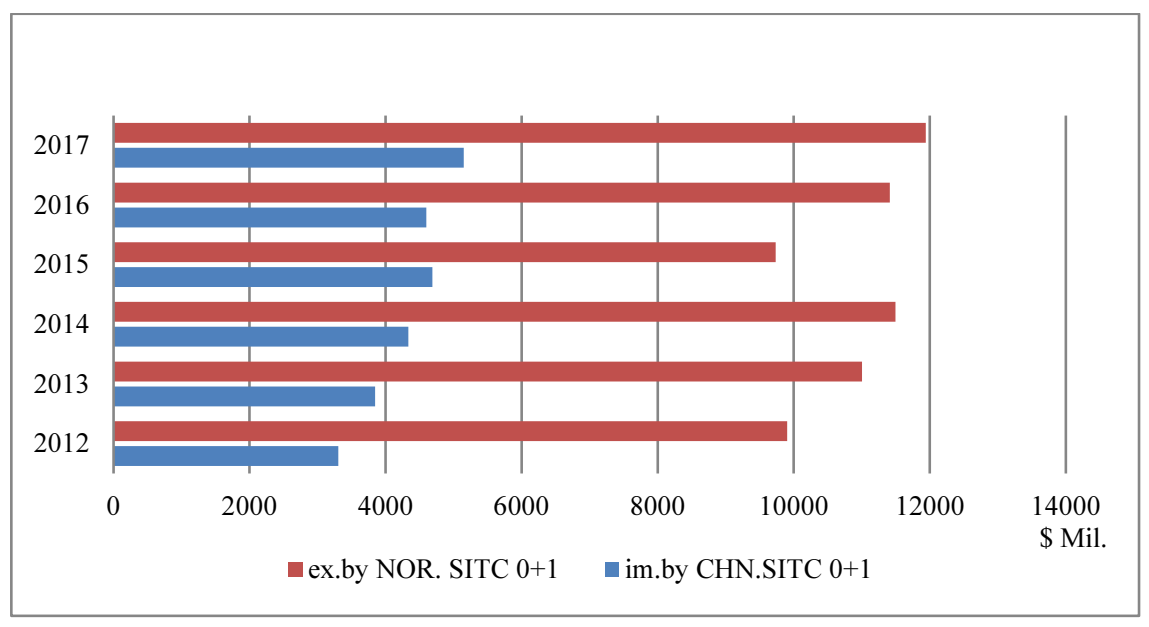

Figure 2. The transaction of SITC 0+1 exported by Norway and imported by China (2012-2017)

Source: The results of Figure 2 is obtained by calculating based on the international trade data of the United Nations, the world trade organization, the bureau of statistics of China and the bureau of statistics of Norway. 
The characteristics of bilateral complementarity demonstrate a low competitiveness, high complementarity, the export advantage of one party being the import disadvantage of the other, strong stability and fast growth. In 2020, the total trade volume between China and Norway was US $\$ 16.175$ billion, an increase of $24.04 \%$ over 2019. China has become the fourth largest trading partner accounting for $9.9 \%$ of Norwegian total goods trade [16].

According to the characteristics of bilateral complementarity, China should expand international trade cooperation with Norway in the following fields: energy and fishing resources, complementary sectors in upstream and downstream industrial chains, and infrastructure linked with machinery and transportation equipment manufacturing. However, the expansion of trade potentiality will be negatively affected by the overall bilateral tariff level. Instead, reaching free trade agreements and improving infrastructure will greatly improve the efficiency of bilateral trade.

\subsection{Tariffs imposed by China on Norwegian trade complementary products}

Chinese tariffs on Norwegian trade complementary products remained at a relatively low level during the period from 2001 to 2017. The average tariffs on SITC 3, SITC 2, SITC 0, and SITC 4 are separately 5.3\%, 7.1\%, 10.3\%, and 12.4\% (see Figure 3).

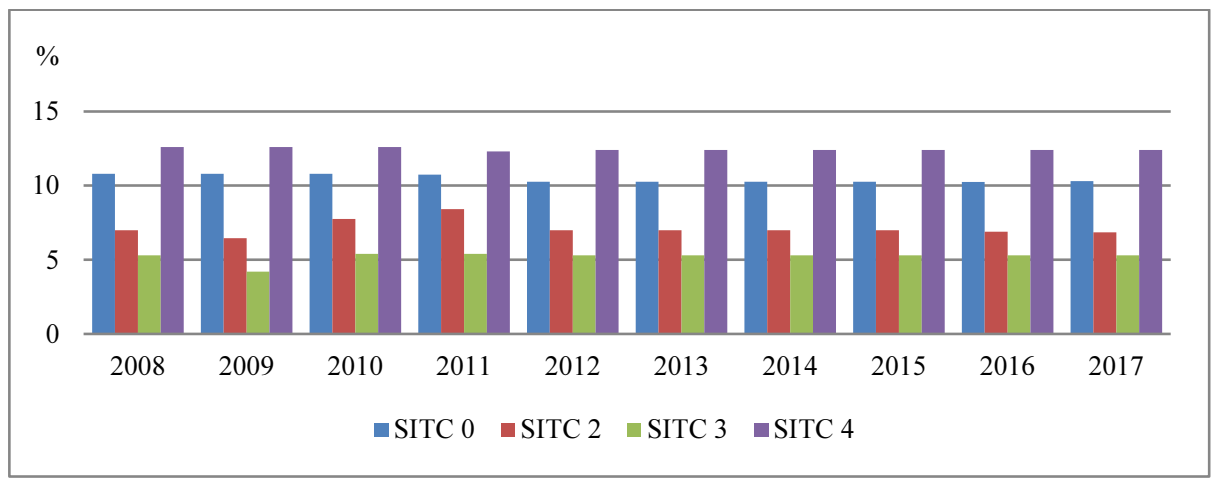

Figure 3. The tariff rate imposed by China on Norwegian trade complementary products (2008-2017)

Source: The results of Figure 3 is obtained by classifying and calculating based on the HS tariff classification data of the WTO.

The TCI of Norwegian SITC $2+4$ to China is 1.6 on average, which implies a strong demand for such products in China. The key constraint to Chinese economic development in the coming period is the shortage of resources. Imposing tariffs on commodities with strong resource complementarity, such as SITC 2 and SITC 0 of Norway, will exacerbate resource shortage in China.

\subsection{Tariffs imposed by Norway on Chinese trade complementary products}

The imposed tariffs on Chinese SITC 6 has been kept at 21\%, even though the tax rate on SITC 6 decreased from $137.9 \%$ in 2001 to $21 \%$ in 2017 in Norway. The Norwegian tariffs on Chinese SITC 7 and SITC 8 has implemented zero tariffs since 2003 (see Figure 4). Nevertheless, non-tariff barriers, technical standards, and value-added tax 
were higher than that of China ${ }^{2}$.

The TCI of Chinese SITC 6 with Norway is as high as 2, and forms an interdependent industrial chain between upstream and downstream in the production process. The results of imposing tariffs on SITC 6 would definitely impact on Norwegian import and consumption demand. Tariff reduction between both sides is the key content of reaching a free trade agreement. Chinese government has been actively promoting signing the free trade agreements. Norwegian foreign minister and finance minister said that "reaching a free trade agreement with China is the top priority of the Norwegian government" [17], and "the tariff agreement is an important prerequisite for trade and investment between Norway and China. Therefore, both sides should consult on it as soon as possible"[18]. In fact, it has always pursued a free trade policy and has independently reduced tariffs for many times in China.

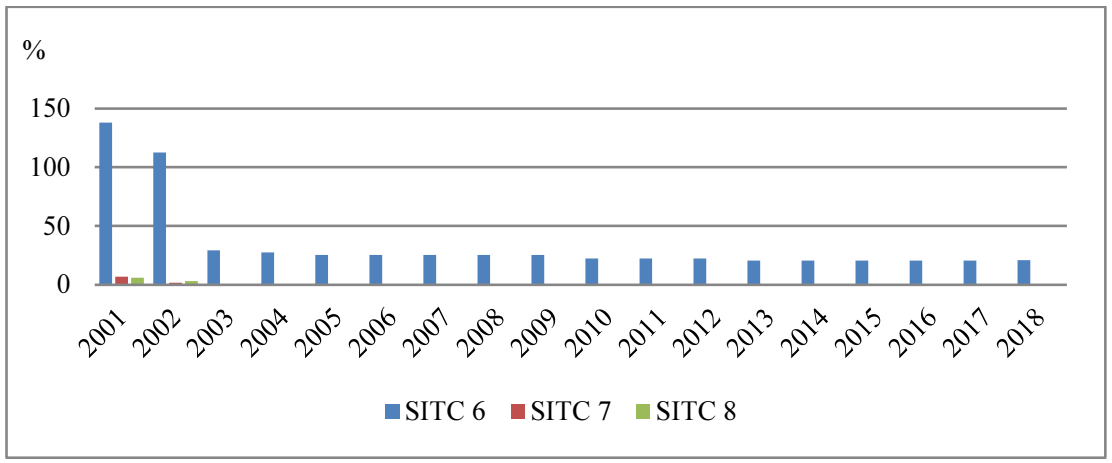

Figure 4. The tariff rate imposed by Norway on Chinese trade complementary goods (2008-2017)

Source: The results of Figure 4 is obtained by classifying and calculating based on the HS tariff classification data of the WTO.

Currently, the world trade pattern, including China, has been changing, that is, promoting free trade zones or regional super large free trade agreements as an important paradigm to enhance economic cooperation among countries, which requires reducing tariffs and expanding exports and imports. The important part of foreign trade development strategy of China has been to expand imports, and to keep the balanced development of import and export [19]. Scholars have demonstrated the economic benefits of lowing tariffs. Based on the tariff reduction schedules of FTA negotiations between China and South Korea, for example, some studies have found that bilateral tariff reductions would promote trade creation, increasing the GDP, boosting import and export and raising welfare by means of the calculation of GTAP model [20, 21]. Furthermore, lowering import tariffs would not only help raising the income, consumption, employment, social welfare, return on capital and output level, but also reduce price level and enhance economic benefits for trade partners. Obviously, imposing tariffs on goods with trade complementarity is not in line with bilateral economic interests in the long-term and decreases social welfare for both sides. It is necessary for jointing efforts to decrease tariff, so that speed up the negotiation process of free trade agreements between China and Norway.

${ }^{2}$ Source: Tariff HS classification data of the WTO from 2013 to 2017. 


\section{Conclusions and suggestions}

Promoting tariff relief for commodities with strong trade complementarity between China and Norway should be taken into account first. The strategies to push up free trade agreement should be step by step.

First, the key of pushing up the negotiation of the free trade agreement between both sides should focus on cutting down tariff on Chinese SITC 6. Chinese side needs to strive for cutting tariff to zero for some overcapacity goods within SITC 6, including textiles, steel products, building materials, non-ferrous metals and glass products, etc., if it is difficult for Norway to reduce the tariff on various commodities of SITC 6 to zero at one time. The tariff on the rest, such as leather products, ceramic products, paper and paperboard products, could be reduced by stages. Concurrently, the increase of investment and consumption demand for SITC 6 in Norway will be benefit from lowering tariff on Chinese SITC 6.

Second, it is important for China to reduce the tariff of $7.1 \%$ on Norwegian SITC 2 and $12.4 \%$ on SITC 4 as priority through signing tariff reciprocity agreement or arranging schedule for tariff reduction. Since SITC 2 and SITC 4 are group commodities with strong trade complementarity with China, of which some goods, such as iron, copper, nickel and aluminum ores, concentrates, raw fur, rubber, oilseeds, wood corks, pulp waste paper, silk, cotton, hemp textile fibers and fats and waxes of animal and vegetable, are all shortage resources in urgent need in China. Reducing the tariff on Norwegian SITC 2 will help to stabilize and to expand the production chain of raw materials and finished products because the group SITC 2 is the upstream products of SITC 6 of China.

Third, SITC 3 of Norway is highly complementary to China and has great trade potentiality. If Chinese tariff on SITC 3 is further reduced on the basis of improving transportation infrastructure, it will greatly stimulate the volume of bilateral trade.

Finally, lowering the tariff of $10.3 \%$ on Norwegian SITC 0 could alleviate the shortage of meat food in China. Although the current TCI of SITC 0 of Norway is less than 1, according to the trend of Chinese meat consumption, the demand for aquatic products of Norway will continue to rise, and the potentiality of supply and demand complementarity of SITC 0 between the two countries is extremely huge.

For the sake of reaching the FTA, both sides should gradually implement zero tariff on trade complementary commodities with strong domestic demand through gradually decreasing the overall tariff level, which will not only help stabilize and improve Chinese position in the international industrial chain and supply chain, but also help to achieve the cooperation of an all-win result between China and Norway.

\section{References}

[1] Li G, Ye X. Discussion on the rationality of Chinese tariff level and tariff structure under the new situation. International Trade Issues. 2017(7): 23-35.

[2] Salvador DE. International Economics. Beijing: Tsinghua University Press; 2011. P. 57.

[3] Robert J, Porter M, Redding S. Specialization dynamics. Journal of International Economics. 2014(58):299-334.

[4] Stack MM, Bliss M. EU economic integration agreements, brexit and trade. Review of World Economics. 2020(5):1-31.

Li G, Ye X. Discussion on the rationality of Chinese tariff level and tariff structure under the new situation. International Trade Issues. 2017(7): 23-35.

[5] Zheng ZY, Meng M. Analysis of the economic effects of the Asia Pacific Free Trade Area. International 
Economic Cooperation. 2017(7): 51-65.

[6] Andreosso-O', Callaghan B. Economic structural complementarity: how viable is the Korea-EU FTA? Journal of Economic Studies. 2009(36):147-167.

[7] Hu Y, Yan JL, Quan Y. Empirical Study on the measurement of trade complementarity between China and countries along the " 21 st century Maritime Silk Road" and its influencing factors. World Economic Research. 2017(8): 39-50.

[8] Liu CP, Xiao HF. China's agricultural trade with North European countries - complementarity, competitiveness and development potential under "one belt and road". Journal of Dalian University of Technology.2019 (4):67-77.

[9] Chen YH, Lai MY. Analysis on trade structure and competitive complementarity between China and Norway. Financial Theory and Practice. 2011(9): 52-65.

[10] Bojnec S, Ferto I. Complementarities of trade advantage and trade competitiveness measures. Applied Economics. 2012(44):399 - 408.

[11] Chen M, Chen SM. The study of potential trade effects of interconnection and interconnection on China under "one belt and road". Modern Economy Exploration. 2019(12): 59-70.

[12] Hofmann C, Alberto O, Michele R, Horizontal D. A new database on the content of deep agreements. Policy Research Working Paper of NBER. 2017(5): 7981-7997.

[13] Zhou XB, Chen Z. The strategic connotation and economic impact of actively expanding imports. Modern Economy Exploration. 2020(2): 17-29.

[14] Aditya A, Acharyya R. Trade liberalization and export diversification. International Review of Economics and Finance. 2015(39):390-410.

[15] Ministry of Climate and Environment. Report to the Storting. Norway. 2015-2016: 1-120.

[16] Yi XL. Bright development prospects of China and the future cooperation between China and Norway. Speech at the annual forum of Chamber of Commerce both Norway and China; Embassy of P. R. China in the Kingdom of Norway, 2021 March 26, Oslo, Norway.

[17] Thured E. Reaching a free trade agreement with China is the top priority of the Norwegian government. Embassy of P. R. China in the Kingdom of Norway. 2018 Aug 23, Oslo. Available online: http://no.mofcom.gov.cn (accessed on 2019 Dec. 26).

[18] Jensen S. Agreement with China to renegotiate tax treaty. Press release. Norwegian government. 2017 Sept. 28, Oslo. Available online: http://www.regjeringen.no (accessed on 2020 Jan. 22).

[19] Zhu QR, Yang L, Wang Y. Evaluation of economic benefits of China's import tariff reduction. World Economy Studies. 2021(2):19-32.

[20] Zhou SD, Xiao X, Yang J. Analysis of the economic influence of the establishment of the China Korea FTA on their major industries based on the tariff reduction schedules of the bilateral FTA negotiation. Issues of International Trade. 2016(5): 116-129.

[21] Lawrence R. World tariff rate declines and progress in global trade liberalization: multilateral, regional and unilateral.

Research on Financial Development. 2021(7): 42-47. 